\title{
O Teatro como Ferramenta de Humanização
}

\author{
Aveiro, Terezinha da Luz Alves; Coalho Junior, Rubens; Franchi, Rosana \\ Aparecida; Caruso, Antônia Gonçalves; Chagas, Maria Elizete das \\ Hospital Municipal Maternidade Escola de Vila Nova Cachoeirinha "Dr. Mário de Moraes A. Silva" — \\ teraluz@gmail.com
}

Introdução: a formação de um grupo de Teatro na Unidade ocorreu por acaso, por ocasião das comemorações de Natal do ano de 2002. a ideia de se representar o nascimento de Jesus com funcionários da Unidade resultou na necessidade de identificar possíveis atores em diversos setores, uma vez que Maria deveria ser uma funcionária grávida, um dos reis magos deveria ser negro, etc. Apesar da enorme dificuldade de ensaio, a apresentação da peça foi um sucesso, inicialmente de público (mais de 100 pessoas), em parte porque os funcionários dos setores representados queriam ver como "se sairia" o seu colega e também por ter suscitado risos e muita emoção, sendo consequentemente muito bem comentada. a partir de então o grupo começou a ser convidado para eventos comemorativos e principalmente quando era necessária a reflexão acerca de um tema, implantação de serviços, etc., funcionando como importante ferramenta nos processos de mudança. Objetivo: Integração, melhora do clima institucional da Unidade e da relação do servidor com o paciente, reflexão sobre comportamentos automáticos, humanização do profissional de saúde. Método Seleção de "atores" de diferentes setores da Unidade. Coleta de informações sobre o assunto a ser abordado e objetivo a ser atingido. Encontros do grupo para montar a peça através da dinâmica "tempestade de idéias. Elaboração do texto da peça. Laboratório, ensaios e apresentação. Reflexão, discussão sobre o tema apresentado. Resultados: Sensibilização e reflexão de servidores sobre diversos temas: implantação de acompanhante nas salas de parto, mãe canguru, aleitamento materno, reciclagem de lixo, etc.. Melhora no clima institucional. Funcionários passaram a cumprimentar-se nos corredores da Unidade, a partir da aproximação dos setores dentro do grupo, formando uma corrente de simpatia. um resultado inesperado foi a melhora de comportamento de uma participante do grupo de teatro dentro de seu próprio setor, em virtude de se sentir valorizada pelo grupo de pertença. Conclusões: o teatro pode ser usado como importante ferramenta de humanização. a situação a ser trabalhada quando projetada em cenas diminui eventuais resistências do expectador propondo-lhe uma visão ampla, permitindo-se colocar no lugar de todos os envolvidos da trama.

Aveiro, Terezinha da Luz Alves; Coalho Junior, Rubens; Franchi, Rosana Aparecida; Caruso, Antônia Gonçalves; Chagas, Maria Elizete das. O Teatro como Ferramenta de Humanização. In: Anais do Congresso Internacional de Humanidades \& Humanização em Saúde [= Blucher Medical Proceedings, num.2, vol.1]. São Paulo: Editora Blucher, 2014. ISSN 2357-7282

DOI 10.5151/medpro-cihhs-10164 